\title{
EVALUASI PENERAPAN GANTI UANG DI DIREKTORAT LALU LINTAS POLDA SULAWESI UTARA
}

\author{
Isma Ardilina ${ }^{1}$, Treesje Runtu ${ }^{2}$, Victorina Z. Tirayoh ${ }^{3}$ \\ 1,2,3 Jurusan Akuntansi, Fakultas Ekonomi dan Bisnis, Universitas Sam Ratulangi, Jl.Kampus Bahu, Manado, \\ 95115, Indonesia
}

E-mail : ismaardilina@ymail.com

\begin{abstract}
Spending treasurer filed SPP-UP the beginning of each fiscal year after the issuance of the Decree on the magnitude Regional Head UP. At the time of Money Supply has been use spending treasurer may submit SPP-GU with a number of different use of Money Supply SPJ which has been passed in a specific time period. PERMENDAGRI NO. 13 of 2006 and PERMEENDAGRI No.55 of 2008 has given a detailed regulation on the administration and preparation of money supply and change of money supply. The purpose of this study was to know implementation of change money of traffic directorate is in compliance with applicable regulation or contrary to existing rules. The analysis method used in this research using descriptive qualitative. The result shows that Traffic Directorate Polda Sulut has made the application of money change in the directorate in accordance with applicable regulation.

Keyword: Treasurer, Money Supply, Change Money
\end{abstract}

\section{PENDAHULUAN}

Suatu pemerintahan yang baik (good governance) adalah pemerintahan yang memiliki karakteristik diakui oleh masyarakat atau memiliki legimitasi, berakuntabilitas, mempunyai kemampuan untuk memformulasikan kebijakan dan menyediakan jasa, dan menghormati hak asasi manusia, serta menjunjung dan menegakkan hukum.Pemerintahan yang baik setidaknya ditandai dengan tiga elemen yaitu transparansi, partisipasi, dan akuntabilitas.

Transparansi dibangun atas dasar kebebasan memperoleh informasi. Partisipasi yaitu membiarkan keterlibatan masyarakat dalam pembuatan keputusan yang baik dan benar secara langsung maupun tidak langsung melalui lembaga perwakilan yang dapat menyalurkan aspirasi dan idenya secara bebas dan luas. Sedangkan akuntabilitas adalah melakukan pertanggungjawaban kepada publik atas setiap aktivitas yang dilakukan. Sistem akuntansi pengeluaran kas merupakan sistem yang digunakan untuk mencatat seluruh transaksi pengeluaran kas. Penatausahaan pengeluaran kas (cash out) adalah salah satu rangkaian dari proses menerima, menyimpan, menyetor, membayar, menyerahkan dan juga mempertanggungjawabkan pengeluaran uang yang ada dalam pengelolaan SKPKD (Satuan Kerja Pengelolaan Keuangan Daerah).

Bendahara Pengeluaran bertugas untuk mengajukan SPP-UP setiap pada awal tahun anggaran sesudah diterbitkannya Surat Keputusan Kepala Daerah Tentang besaran Uang Persediaan. Pada saat Uang Persediaan sudah habis di pakai, Bendahara Pengeluaran bisa mengajukan SPP-GU sama besar dengan jumlah SPJ penggunaan Uang Persediaan yang sudah disahkan pada periode waktu tertentu. PERMENDAGRI Nomor 13 Tahun 2006 dan PERMENDAGRI Nomor 55 Tahun 2008 telah memberikan Peraturan yang detail tentang Penatausahaan dan Penyusunan Uang Persediaan serta Ganti Uang Persediaan. Tujuan penelitian ini adalah untuk mengetahui penerapan Ganti Uang di Direktorat Lalu Lintas Polda Sulut. 


\section{TINJAUAN PUSTAKA}

\subsection{Pengertian Akuntansi}

Menurut PP No. 71 Tahun 2010 (Standar Akuntansi Pemerintahan), akuntansi merupakan sesuatu bentuk proses identifikasi, pengukuran, pengklasifikasian, pengikhtisaran transaksi dan kejadian keuangan, penyajian laporan, serta penginterpretasian atas hasilnya. Dilihat secara umum tujuan akuntansi adalah menyajikan informasi ekonomi dari satu kesatuan ekonomi kepada pihak-pihak yang berkepentingan.Sedangkan hasil dari proses akuntansi yang berbentuk laporan keuangan yang diharapkan dapat membantu bagi pemakai informasi keuangan.

\subsection{Pengertian Akuntansi Sektor Publik}

Menurut Wiratna (2015:1) Akuntansi sektor publik dapat didefinisikan sebagai aktivitas jasa yang terdiri dari mencatat, mengklasifikasikan dan melaporkan kejadian atau transaksi ekonomi yang akhirnya akan menghasilkan suatu informasi keuangan yang akan dibutuhkan oleh pihak-pihak tertentu untuk pengambilan keputusan yang diterapkan pada pengelolaan dana publik di lembaga-lembaga tinggi Negara dan departemen-departemen dibawahnya.

\subsection{Tujuan dan Fungsi Laporan Keuangan Sektor Publik}

Deddy Nordiawan dan Ayuningtyas (2014:125) dalam buku "Akuntansi Sektor Publik menjeaskan tujuan dan juga fungsi laporan keuangan sektor publik sebagai berikut :

1. Kepatuhan dan Pengelolaan (compliance and stewardship).

Laporan keuangan dimanfaatkan atau di gunakan untuk memberikan fasilitas jaminan kepada para pengguna laporan keuangan dan pihak otoritas penguasa, bahwa pengelolaan sumber daya telah dilaksanakan atau dilakukan sesuai dengan ketentuan hukum dan peraturan lainnya yang telah ditetapkan.

2. Akuntabilitas dan laporan retrospektif (accountability and retrospective reporting).

Laporan keuangan digunakan sebagai bentuk pertanggungjawaban kepada publik. Laporan keuangan digunakan untuk mengawasi kerja dan mengevaluasi manajemen, memberikan dasar untuk tren antar kurun waktu, pencapaian atas tujuan yang telah ditetapkan, dan membandingkannya dengan kinerja organisasi lain yang sejenis jika ada.

3. Perencanaan dan informasi otorisasi (planning and authorization information).

Laporan keuangan berfungsi memberikan dasar perencanaan kebijakan dan aktivitas di masa mendatang.Laporan keuangan berfungsi memberikan informasi pendukung mengenai otoritas penggunaan data.

4. Kelangsungan organisasi (viability).

Laporan keuangan berfungsi membantu pengguna untuk memastikan bahwa, apakah suatu organisasi atau juga unit kerja dapat melanjutkan penyediaan barang dan jasa (pelayanan) dimasa yang akan datang mendatang.

5. Hubungan masyarakat (public relation).

Laporan keuangan mempunyai fungsi untuk memberikan kesempatan kepada organisasi untuk menunjukkan pernyataan atas prestasi yang telah didapat kepada pengguna yang dipengaruhi karyawan dan masyarakat. Laporan keuangan berfungsi sebagai alat komunikasi dengan publik dan pihak-pihak lain yang berkepentingan.

6. Sumber fakta dan gambarannya (source of facts and figure).

Laporan keuangan mempunyai tujuan memberikan informasi kepada kelompokkelompok yang berkepentingan ingin megetahui organisasi secara lebih dalam dan jelas.

\subsection{Akuntansi Pemerintahan}

Bachtiar Arif (2012:3) menjelaskan akuntansi pemerintahan adalah sebagai suatu aktivitas atau kegiatan pemberian jasa untuk memberikan informasi keuangan pemerintah berdasarkan proses pencatatan, pengklasifikasian, pengikhtisaran suatu transaksi keuangan pemerintah dan juga penjelasan atas informasi keuangan tersebut. 


\subsection{Sistem Akuntansi Pemerintah Daerah}

Sistem akuntansi pemerintah daerah adalah suatu serangkaian prosedur yang diawali dari proses pengumpulan data, pencatatan, pengikhtisaran, sampai dengan pelaporan keuangan, dalam rangka pertanggungjawaban pelaksanaan APBD yang dapat dilakukan secara manual atau menggunakan aplikasi komputer. Mulalinda (2014) Tujuan sistem akuntansi pemerintah daerah antara lain, menjaga aset melalui pencatatan, pemprosesan dan pelaporan transaksi keuangan yang konsisten, menyediakan informasi yang akurat dan tepat waktu tentang anggaran dan kegiatan keuangan yang berguna sebagai dasar penilaian kinerja untuk menentukan ketaatan terhadap otorisasi anggaran.

\subsection{Akuntansi Keuangan Daerah Secara Umum}

Longdong (2013) Akuntansi keuangan daerah adalah serangkaian proses baik manual maupun secara komputerisasi, mulai dari pengumpulan data, pencatatan, pengikhtisaran, hingga laporan keuangan dan operasi keuangan pemerintah. Akuntansi keuangan daerah dapat dijelaskan sebagai suatu proses pencatatan, penggolongan, dan pengikhtisaran dengan beberapa cara tertentu dalam ukuran moneter, transaksi dan kejadian - kejadian yang umumnya bersifat keuangan dan termasuk pelaporan hasil - hasilnya dalam penyelenggaraan urusan pemerintahan menurut asas otonomi seluas - luasnya dalam sistem dan prinsip Negara Kesatuan Republik Indonesia.

\subsection{Ganti Uang (GU)}

Aji Prabowo (2016) menjelaskan pada saat uang persediaan telah terpakai bendahara pengeluaran dapat mengajukan SPP Ganti Uang Persediaan dengan besaran sejumlah SPJ penggunaan uang persediaan yang telah disahkan pada periode waktu tertentu. SPP-GU tersebut dapat disampaikan untuk satu kegiatan tertentu atau beberapa kegiatan sesuai dengan kebutuhan yang ada.

\subsection{Penelitian Terdahulu}

1. Penelitian yang dilakukan oleh Andrew Marco Saputra (2013) dalam penelitiannya yang berjudul Analisis Penerapan Sistem dan Prosedur Pengeluaran Kas pada BPBD SULUT. Metode penelitian yang digunakan Deskriptif Kualitatif. Tujuannya adalah untuk mengetahui apakah penerapan sistem dan prosedur pengeluaran kas pada BPBD Provinsi Sulawesi Utara sudah sesuai dengan aturan. Hasil penelitian menunjukkan bahwapelaksanaan sistem dan prosedur sudah sesuai dengan Undang-Undang.

2. Penelitian yang dilakukan oleh Pangalila (2015) dalam penelitiannya yang berjudul Analisis sistem dan prosedur penerimaan kas Pendapatan Asli Daerah (PAD) di Kabupaten Minahasa Utara. Metode penelitian yang digunakan Deskriptif Kualitatif. Tujuannya adalah untuk mengetahui penerapan sistem dan prosedur penerimaan kas pada Dinas Pendapatan Pengelolaan Keuangan dan Aset Daerah di Kabupaten Kepulauan Talaud. Hasil penelitian menunjukkan bahwa sistem dan prosedur penerimaan kas PAD pada Kabupaten Minahasa Utara sudah emadai dengan PP No. 24 tahun 2005 tentang Standar Akutansi Pemerintahan namun masih terkendala dengan terbatasnya SDM dalam menjalankan sebagian bidang dari DPPKAD Kabupaten Minahasa Utara.

3. Penelitian yang dilakukan oleh Rachmad Sandy Ramadhan dan Akie Rusaktiva Rustam (2013) dalam penelitiannya yang berjudul Analisis Penyajian Laporan Keuangan Pemerintahan Kabupaten Tulungagung. Metode penelitian yang digunakan Deskriptif Kualitatif. Tujuannya adalah untuk mengetahui sistem penyajian keuangan yang diterapkan pemerintahan kabupaten Tulungagung. Hasil penelitian menunjukkan bahwa berdasarkan komponen laporan keuangannya BPKAD Kabupaten Tulungagung telah mengikuti SAP No. 71 Tahun 2010. Namun pada laporan realisasi anggarannya, pada penyajian pos pembiayaan masih belum di konversi menurut SAP dan masih mengikuti klasifikasi atau pemberian nama pos menurut permendagri atau menurut pos pembiayaan didalam APBD pemkab Tulungagung. 
4. Penelitian yang dilakukan oleh Sitti Maryam Mohammad, Jantje Tinangon dan Enggriani Elim (2014) dalam penelitiannya yang berjudul Evaluasi Penerapan Akuntansi untuk Belanja Modal berdasarkan peraturan Pemerintah No. 71 Tahun 2010 pada Dinas PU Kota Manado. Metode penelitian yang digunakan Deskriptif Kualitatif. Tujuannya adalah untuk mengetahui bagaimana penerapan akuntansi untuk belanja modal yang di dasarkan pada PP No71 tahun 2010 pada Dinas PU Kota Manado. Hasil penelitian menujukkan bahwa Akuntansi untuk belanja modal pada Dinas PU Kota Manado sudah sesuai dengan PP no71 tahun 2010.

5. Penelitian yang dilakukan oleh Mawikere (2016) dalam penelitiannya yang berjudul Analisis Sistem dan Prosedur penerimaan Retribusi Kebersihan Daerah Pada Dinas Pendapatan Daerah Kota Manado. Metode penelitian yang digunakan Deskriptif Kualitatif. Tujuannya adalah untuk mengetahui Sistem dan Prosedur Penerimaan Retribusi Kebersihan Daerah Pada Dinas Pendapatan Daerah Kota Manado. Hasil penelitian menujukkan bahwa Sistem dan Prosedur Penerimaan Retribusi Kebersihan Daerah telah sesuai dengan PERMENDAGRI No. 59 tahun 2007.

\section{METODE PENELITIAN}

\subsection{Jenis Penelitian}

Jenis yang Penelitian di gunakan dalam penelitian ini adalah jenis penelitian yang bersifat Metode Kualitatif. Sugiono (2014) mengenai jenis-jenis metode penelitian dapat diklarifikasikan berdasar tujuan dan tingkat kealamiahan objek yang di teliti, Penelitian Kualitatif adalah penelitian yang di gunakan untuk mendeskripsikan dan menganalisis suatu fenomena, suatu peristiwa, aktivitas sosial, sikap kepercayaan, presepsi dan orang secara individual maupun kelompok.

\subsection{Waktu dan tempat penelitian}

Lokasi penelitian yang di teliti penulis bertempat di Direktorat Lalu Lintas Polda Sulut jalan Bethesda Kecamatan Sario Kota Manado Provinsi Sulawesi Utara.Waktu penelitian di laksanakan pada bulan Maret 2018.

\subsection{Jenis Data}

Data adalah kumpulan - kumpulan informasi yang diperlukan dalam pengambilan keputusan. Indriantoro dan Supomo (2011 : 115) menyatakan bahwa jenis data terbagi dua, yaitu :

- Data kualitatif merupakan data yang disajikan atau ditunjukkan dalam bentuk kata-kata yang mengandung makna dan tidak bisa dikuantitatifkan.

- Data kuantitatif merupakan data yang berupa angka-angka atau nilai.

Jenis data yang digunakan dalam penelitian ini adalah Data Kualitatif berupa data penerapan ganti uang di Direktorat Lalu Lintas Polda Sulut.

\subsection{Sumber Data}

Indriantoro dan Supomo (2011 : 146) menyatakan bahwa sumber data penelitian terbagi menjadi 2 yaitu :

1. Data primer

Data primer adalah sumber data penelitian yang diperoleh secara langsung dari sumber asli (objek yang akan diteliti, tidak melalui media perantara). Data primer secara khusus dikumpulkan oleh para beberapa peneliti untuk menjawab pertanyaan penelitian.

2. Data sekunder

Data sekunder adalah sumber penelitian yang diperoleh atau didapatkan peneliti secara tidak langsung atau melalui media perantara (diperoleh dan dicatat oleh pihak lain). Data sekunder umumnya merupakan bukti dari beberapa catatan atau laporan historis yang sudah tersusun dalam arsip (data documenter) yang dipublikasikan maupun yang tidak dipublikasikan. 
Dalam penelitian ini, peneliti menggunakan data promer berupa data yang diperoleh langsung dari objek penelitian. Sedangkan data sekunder yang digunakan adalah dari literatur - literatur, buku yang bersangkutan dengan judul penelitian, serta artikel yang dibuat oleh pihak ketiga dan mempunyai reverensi dengan penelitian ini.

\subsection{Metode Analisis}

Metode analisis data yang digunakan dalam penelitian ini adalah analisis deskriptif. Analisis deskriptif merupakan dimana tingkat atau level pekerjaannya mencakup cara - cara pengumpulan, menyusun atau mengatur, mengolah, menyajikan dan menganalisis data agar dapat memberikan gambaran yang teratur, ringkas dan jelas mengenai keadaan, peristiwa, atau gejala tertentu sehingga dapat ditarik pengertian atau makna tertentu.

\section{HASIL PENELITIAN DAN PEMBAHASAN}

\subsection{Hasil Penelitian}

Peneliti melakukan penelitian di Direktorat Lalu Lintas Polda Sulut pada tanggal 20 April 2018. Peneliti mengajukan beberapa pertanyaan secara lisan kepada Bendahara Pengeluaran dan kepada salah seorang pegawai bagian keuangan, kemudian Narasumber (Bendahara Pengeluaran dan pegawai bagian keuangan) menjawab sesuai pertanyaan yang diajukan. Pertanyaan yang peneliti lakukan adalah pertanyaan berdasarkan penerapan ganti uang persediaan yang ditetapkan diberbagai peraturan yang saat ini berlaku, kemudian narasumber menjawab sesuai dengan praktik yang sesungguhnya dilakukan, sehingga nantinya peneliti bisa menganalisis bagaimana penerapan ganti uang yang diterapkan di Direktorat Lalu Lintas Polda Sulut tersebut.

\subsubsection{Penerapan Ganti Uang di Direktorat Lalu Lintas Polda Sulut}

a. Pengajuan Surat Perintah Pembayaran Ganti Uang

Untuk Ganti Uang (GU) sendiri dapat diajukan ketika Uang Persediaan (UP) telah dikeluarkan, dalam hal ini dikeluarkannya Surat Perintah Pencairan Dana (SP2D) dari Bendahara Pengeluaran untuk Uang Persediaan (UP) di setiap Satker.

b. Pembuatan SPP-GU

Untuk prosesnya, Direktorat lalu lintas Polda Sulut menerapkan proses dalam mengajukan Ganti Uang (GU) yaitu sebagai berikut :

- Adanya usulan Anggaran Kas Perbulan

- Setelah itu diterbitkannya Surat Penyediaan Dana untuk Ganti Uang

- Membelanjakan Uang Persediaan (UP) yang telah dikeluarkan dengan menggunakan bukti-bukti seperti Kwitansi Pembayaran sebagai Bukti Penerimaan Keuangan (BPK) dengan lampiran-lampirannya, bisa juga menggunakan nota, atau yang lainnya.

- Setelah itu diinput ke aplikasi dengan menggunakan perangkat komputer dan kemudian dibuatlah Surat Pertanggung Jawaban untuk Ganti Uang (SPJ-GU).

- Setelah dibuatnya Surat Pertanggung Jawaban Ganti Uang (SPJ-GU) kemudian diajukan ke PPK-Ditlantas yaitu Bendahara Satuan Ditlantas Polda Sulut.

- Setelah itu dikeluarkan dan diterbitkannya SPP-GU. Untuk lampiran dari SPP-GU terdiri dari SPJ dan bukti-bukti kwitansi yang ada. Sedangkan untuk rincian SPP-GU terdiri dari Surat Pengantar, Ringkasan dan Uraian.

c. Pembuatan SPM-GU

Untuk membuat SPM-GU, PPK-Ditlantas meneliti kelengkapan atas SPP-GU berdasarkan SPD dan DPA-Ditlantas, apabila SPP-GU dinyatakan lengkap maka PPKDitlantas membuat SPM-UP paling lambat 2 hari kerja sejak SPP-UP di terima. Rancangan SPM ini kemudian diberikan PPK-Ditlantas kepada pengguna anggaran untuk diotorisasi. Jika SPP-GU di nyatakan tidak lengkap, PPK-Ditlantas akan menerbitkan surat penolakan SPM paling lambat 1 hari kerja sejak SPP-GU di terima. Surat penolakan penerbitan SPM ini kemudian diberikan PPK-Ditlantas kepada pengguna anggaran untuk 
diotorisasi. Surat penolakan penerbitan SPM di berikan kepada bendahara agar bendahara melakukan penyempurnaan SPP-GU.

d. Penerbitan SP2D-GU

Setelah Surat Perintah Membayar Ganti Uang (SPM-GU) dikeluarkan dan diterbitkan kemudian ditanda tangani oleh Kapolda untuk diajukan ke Bendahara Umum atau pengguna anggaran untuk dikeluarkannya atau diterbitkannya Surat Perintah Pencairan Dana untuk Ganti Uang (SP2D-GU)

\subsection{Pembahasan}

Perbandingan PERMENDAGRI ( Peraturan Daerah Dalam Negeri ) Nomor 55 Tahun 2008 dengan Peraturan Dit Lantas Polda Sulawesi Utara

\begin{tabular}{|c|c|c|c|}
\hline & Permendagri No 55 Tahun 2008 & Dit Lantas Polda Sulut & Keterangan \\
\hline $\begin{array}{l}\text { Pengajuan } \\
\text { Surat } \\
\text { Permintaan } \\
\text { Pembayaran } \\
\text { untuk UP dan } \\
\text { GU }\end{array}$ & $\begin{array}{l}\text { Bendahara pengeluaran SKPD } \\
\text { mengajukan Surat Permintaan } \\
\text { Pembayaran (SPP) dalam rangka } \\
\text { melaksanakan belanja. Dalam hal } \\
\text { ini bendahara pengeluaran } \\
\text { menyusun dokumen SPP yang } \\
\text { terdapat beberapa macam dan } \\
\text { diantaranya adalah Uang } \\
\text { Persediaan (UP) dan Ganti Uang } \\
\text { (GU) }\end{array}$ & $\begin{array}{l}\text { Berdasarkan SPD tersebut } \\
\text { bendahara membuat SPP-UP } \\
\text { beserta rincian dokumen } \\
\text { lainnya yang terdiri dari surat } \\
\text { pengantar, ringkasan dan } \\
\text { rincian, salinan SPD, surat } \\
\text { pernyataan pengguna anggaran } \\
\text { dan lampiran lain seperti daftar } \\
\text { rincian rencana penggunaan } \\
\text { dana s/d jenis belanja }\end{array}$ & Sesuai \\
\hline $\begin{array}{l}\text { Surat Perintah } \\
\text { Pembayaran } \\
\text { Uang } \\
\text { Persediaan }\end{array}$ & $\begin{array}{l}\text { Berdasarkan SPD tersebut } \\
\text { bendahara membuat Surat } \\
\text { Permintaan Pembayaran untuk UP } \\
\text { atau disebut SPP-UP beserta } \\
\text { rincian dokumen lainnya yang } \\
\text { terdiri dari surat pengantar, } \\
\text { ringkasan dan rincian, salinan } \\
\text { SPD, Surat Pernyataan } \\
\text { Penggunaan Anggaran dan } \\
\text { lampiran lain seperti daftar rincian } \\
\text { rencana penggunaan dana s/d jenis } \\
\text { belanja. }\end{array}$ & $\begin{array}{l}\text { Untuk penggunaan UP dalam } \\
\text { Satker di Ditlantas Polda Sulut, } \\
\text { UP yang diterapkan Ditlantas } \\
\text { Polda Sulut di tetapkan } \\
\text { berdasarkan SK Kapolda } \\
\text { tentang besaran UP di setiap } \\
\text { Satker, hal ini dilakukan setiap } \\
\text { awal tahun anggaran. Dalam } \\
\text { hal ini tidak seperti GU yang } \\
\text { dilakukan berulang-ulang } \\
\text { dalam setiap tahun anggaran. } \\
\text { UP sendiri dipergunakan untuk } \\
\text { mengisi uang muka Satker } \\
\text { dalam menjalankan kegiatan } \\
\text { operasional sehari hari selama } \\
\text { satu tahun anggaran. }\end{array}$ & Sesuai \\
\hline $\begin{array}{l}\text { Dokumen- } \\
\text { dokumen atau } \\
\text { lampiran Surat } \\
\text { Perintah } \\
\text { Pembayaran } \\
\text { UP }\end{array}$ & $\begin{array}{l}\text { Bendahara mempersiapkan } \\
\text { dokumen }- \text { dokumen yang } \\
\text { diperlukan sebagai lampiran } \\
\text { dalam pengajuan SPP-UP, selain } \\
\text { dari dokumen SPP-UP itu sendiri. } \\
\text { Lampiran tersebut antara lain: } \\
\text { a. Salinan SPD } \\
\text { b. Draft surat pernyataan } \\
\text { penggunaan anggaran } \\
\text { c. Lampiran lain yang di } \\
\text { perlukan }\end{array}$ & $\begin{array}{l}\text { Berdasarkan SPD tersebut } \\
\text { bendahara SPP-UP beserta } \\
\text { rincian dokumen lainnya yang } \\
\text { terdiri dari surat pengantar, } \\
\text { ringkasan dan rincian salinan } \\
\text { SPD, surat pernyataan } \\
\text { pengguna anggaran dan } \\
\text { lampiran lain seperti daftar } \\
\text { rincian rencana pengguna dana } \\
\text { s/d jenis belanja }\end{array}$ & Sesuai \\
\hline $\begin{array}{l}\text { Proses, sistem } \\
\text { dan prosedur } \\
\text { pencatatan UP }\end{array}$ & $\begin{array}{l}\text { Dalam Permendagri semua } \\
\text { pencatatan maupun pelaporan } \\
\text { yang dilakukan atas UP dan GU }\end{array}$ & $\begin{array}{l}\text { Untuk proses, sistem dan } \\
\text { prosedur pencatatan UP } \\
\text { maupun GU di Dit Lantas }\end{array}$ & $\begin{array}{l}\text { Tidak } \\
\text { Sesuai }\end{array}$ \\
\hline
\end{tabular}




\begin{tabular}{|c|c|c|c|}
\hline & Permendagri No 55 Tahun 2008 & Dit Lantas Polda Sulut & Keter \\
\hline dan GU & $\begin{array}{l}\text { dilakukan menggunakan oprating } \\
\text { sistem komputer dengan cara } \\
\text { penggunaan manal. }\end{array}$ & $\begin{array}{l}\text { Polda Sulut dilakukan dengan } \\
\text { menggunakan operatig sistem } \\
\text { berbasis komputer yang sudah } \\
\text { didukung dengan menggunakan } \\
\text { aplikasi, semua pencatatan dan } \\
\text { pelaporan yang dibuat } \\
\text { menggunakan aplikasi tidak } \\
\text { dengan manual lagi. }\end{array}$ & \\
\hline $\begin{array}{l}\text { Surat Perintah } \\
\text { Pembayaran } \\
\text { Ganti Uang }\end{array}$ & $\begin{array}{l}\text { Pada saat UP telah terpakai, } \\
\text { bendahara pengeluaran dapat } \\
\text { mengajukan SPP-GU dengan } \\
\text { besaran sejumlah SPJ penggunaan } \\
\text { UP yang telah disahkan pada } \\
\text { periode waktu tertentu. SPP-GU } \\
\text { tersebut dapat disampaikan untuk } \\
\text { satu kegiatan tertentu atau } \\
\text { beberapa kegiatan sesuai dengan } \\
\text { kebutuhan yang ada. }\end{array}$ & $\begin{array}{l}\text { Untuk GU sendiri dapat } \\
\text { diajukan ketika UP telah } \\
\text { dikeluarkan., dalam hal ini } \\
\text { dikeluarkannya Surat Perintah } \\
\text { Pencairan Dana (SP2D) dari } \\
\text { Bendahara Polda untuk UP di } \\
\text { setiap Satker. }\end{array}$ & \\
\hline $\begin{array}{l}\text { Dokumen }- \\
\text { dokumen atau } \\
\text { lampiran surat } \\
\text { perintah } \\
\text { pembayaran } \\
\text { UP }\end{array}$ & $\begin{array}{l}\text { Bendahara mempersiapkan } \\
\text { dokumen - dokumen yang di } \\
\text { perlukansebagai lampiran dalam } \\
\text { pengajuan SPP-GU, selain dari } \\
\text { dokumen SPP-GU itu sendiri. } \\
\text { Lampiran tersebut antara lain, } \\
\text { yaitu salinan SPD, Draft surat } \\
\text { pernyataan pengguna anggaran, } \\
\text { laporan pertanggungjawaban UP, } \\
\text { bukti - bukti belanja yang lengkap } \\
\text { dan sah, dan lampiran lain yang } \\
\text { diperlukan. }\end{array}$ & 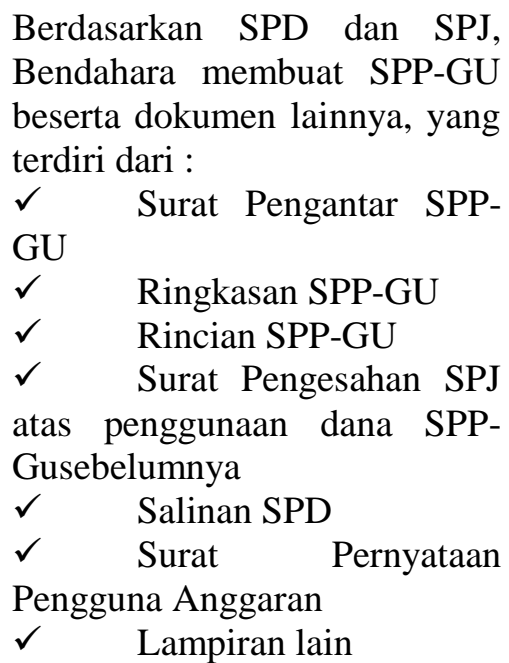 & Ses \\
\hline
\end{tabular}

\subsubsection{Evaluasi atas Ganti Uang Persediaan}

Sistem pngeluaran Kas atas Ganti Uang (GU) pada Direktorat Lalu Lintas Polda Sulut dengan fungsi yang dilaksanakan, adanya usulan anggaran, diterbitkannya SPD (Surat Penyediaan Dana). Bukti - atas belanja Uang Persediaan, menginput ke dalam perangkat komputer untuk dibuatnya SPJ (Surat Pertanggungjawaban) untuk dikeluarkannya SPP (Surat Perintah Pembayaran) atas Ganti Uang (GU) beserta rincian yang ada, pembuatan SPM (Surat Perintah Membayar) berdasarkan kelengkapan atas SPP (Surat Perintah Pembayaran) untuk dokumen yang tidak lengkap akan dikembalikan dan akan diotorisasi, dokumen yang dinyatakan lengkap akan dibuat SPM (Surat Perintah Membayar) paling lambat 1 hari sejak SPP diterima, untuk selanjutnya ditanda tangani untuk diajukan ke pengguna anggaran untuk dikeluarkannya atau diterbitkannya SP2D (Surat Perintah Pencairan Dana) atas GU (Ganti Uang). 


\subsubsection{Evaluasi Mekanisme Pengeluaran Kas atas Uang Persediaan (UP)}

Mekanisme pengeluaran atas Uang Persediaan (UP) Ditlantas Polda Sulut hanya dapat digunakan untuk pengeluaran rutin Satker dan pengeluaran pada program dan kegiatan belanja atas barang maupun jasa. Untuk Uang Persediaan (UP) yang telah terpakai akan diisi kembali dengan menggunakan mekanisme Ganti Uang (GU).

\subsubsection{Evaluasi Dokumen Yang Diperlukan}

Dokumen yang digunakan dalam sistem pengeluaran kas atas Uang Persediaan (UP) dalam bentuk Ganti Uang (GU) pada Direktorat Lalu Lintas Polda Sulut sudah cukup baik dan digunakan sebagaimana mestinya. Surat Penyediaan Dana (SPD) berdasarkan permintaan dari Satker dikeluarkan oleh PPK selaku BU (Bendahara Umum). Surat Perintah Membayar (SPM) yang ditandatangani oleh pengguna anggaran sebagai persetujuan pencairan dana diverifikasi oleh PPK-Satker.

\section{KESIMPULAN DAN SARAN}

\subsection{Kesimpulan}

Berdasarkan hasil penelitian dan pembahasan maka dapat diambil kesimpulan bahwa Direktorat Lalu Lintas Polda Sulut telah melaksanakan penerapan Ganti Uang sesuai dengan peraturan yang berlaku yang saat ini digunakan. Bendahara penerimaan maupun pengeluaran telah melakukan penatausahaan dan penyusunan laporan pertanggungjawaban serta pencatatan atas Ganti Uang yang dimana hal ini juga sudah berdasarkan atau sudah sesuai dengan Peraturan Menteri Dalam Negeri Nomor 13 Tahun 2006 dan Peraturan Menteri Dalam Negeri Nomor 55 Tahun 2008. Masalah - masalah yang sering dihadapi Ditlantas Polda Sulut yaitu dalam melaksanakan Peraturan Daerah Dalam Negeri Nomor 55 Tahun 2008 yaitu seperti kekeliruan dalam hal pelaksanaan pencatatan prosedur yang terkadang harus menyamping dalam hal tersebut, kesalahan dalam pencatatan atas kekeliruan yang dihadapi dalam hal ini biasanya terjadi pada Satkernya sendiri, keterlambatan dalam penyusunan dan penyampaian laporan pertanggungjawaban yang menyebabkan kinerja Direktorat tidak maksimal.

\subsection{Saran}

Berdasarkan kesimpulan diatas maka saran yang dapat diberikan kepada Direktorat Lalu Lintas Polda Sulut yaitu sebagai berikut :

1. Dalam hal penyusunan maupun pencatatan atas Uang Persediaan dan Ganti Uang dengan menggunakan sistem operasi komputer berbasis aplikasi sebaiknya lebih dipelajari untuk cara kerja dan aplikasi tersebut.

2. Untuk Direktur Ditlantas Polda Sulut harus melaksanakan pengawasan maupun pengontrolan secara teratur dab konsistenti terhadap satker - satker agar kinerja atas kegiatan operasional dapat lebih dimaksimalkan.

3. Untuk standart penetapan penempatan personil di bagian keuangan, ada baiknya mengutamakan personil yang memiliki kemampuan ataupun keahlian dengan latar belakang pendidikan akuntansi.

4. Melakukan penambahan dan pelayanan kualitas atas peralatan yng digunakan dalam pengoprasian kegiatan satker agar lebih dipermudahkan.

\section{DAFTAR PUSTAKA}

Deddi, Nordiawan. 2010. Akuntansi Pemerintahan.Jakarta. Salemba Empat.

Halim dan Kusufi,2012. Akuntansi Sektor Publik, Akuntansi Keuangan Daerah Edisi Empat. Penerbit : Erlangga, Jakarta.

Icuk Rangga Bawono, Mochammad Novsyah. (2011). Tata Cara Penatausahaan dan Pertanggungjawaban Bendahara pada SKPD dan SKPKD. Salemba Empat. 
Indriantoro,Nur dan Bambang Supomo. 2011, Metodologi Penelitian Bisnis Untuk Akuntansi Dan Manajemen", Edisi Pertama. BPFE,Yogyakarta.

Nordiawan, Deddy 2011.Akuntansi Pemerintahan. Salemba Empat. Jakarta

Panambunan, Greivy.2016. Evaluasi Pengendalian Internal dalam Pelaksanaan Sistem dan Prosedur Pengeluaran Kas pada Dinas Koperasi dan UMKM Sulawesi Utara. Jurnal Emba. Vol.4 No.1 Maret 2016.Hal.907-915.ISSN 2303-1174.

Peraturan Menteri Dalam Negeri No.13 Tahun 2006 Tentang Pedoman Pengelolaan Keuangan Daerah.

Peraturan Menteri Dalam Negeri No.13 Tahun 2008 Tentang Pokok - pokok Pengelolaan Keuangan Daerah.

Peraturan Pemerintah No. 24 Tahun 2005 tentang Standar Akuntansi Pemerintahan.

Peraturan Pemerintah Republik Indonesia Nomor 71 Tahun 2010.Standar Akuntansi Pemerintahan.Salemba Empat. Jakarta.

Priyati, Novi. 2013. Pengantar Akuntansi. Penerbit Indeks. Jakarta.

Rachamat Sandy Ramadhan dan Akie Rusaktiva Rustam, (2013),Analisis Penyajian Laporan Keuangan Kabupaten Tulungagung, Jurnal, "http://jimfeb.ubac.id/index.php/jimfeb/article/view/902.

Schmidt, Mary, 2016. Accountant and Accounting Explained Definition and Meaning in Business. Business Encylopedia.ISBN 978-929500-109.https://webcache.googleusercontent.com_di akses Januari 292016.

Saputra, Andrew Marcow. (2013), Analisis Penerapan Sistem dan Prosedur Pengeluaran Kas pada BPBD SULUT, Jurnal EMBA, Vol 1. No.3, Http://Ejournal.Unsrat.Ac.Id/Index.Php/Emba/Article/View/ 